\title{
Productivity and drought tolerance of cassava cultivars in the Coastal Tablelands of Northeastern Brazil
}

\author{
Produtividade e tolerância à deficiência hídrica de cultivares \\ de mandioca nos Tabuleiros Costeiros do Nordeste
}

\author{
Luciana Marques de Carvalho $^{I^{*}}$ Hélio Wilson Lemos de Carvalho ${ }^{I}$ \\ Ivênio Rubens de Oliveira ${ }^{\text {II }}$ Marco Antônio Sedrez Rangel ${ }^{\text {III }}$ Vanderlei da Silva Santos ${ }^{\text {III }}$
}

\section{ABSTRACT}

Ten cassava cultivars were grown in the field and evaluated to identify the most adapted to the Coastal Tablelands of northeast Brazil. The cultivars showed differences in proline and chlorophyll contents, plant height, number of leaves and branches, canopy area and root production, however they did not differ on photosynthetic rates. Cultivars 'Tianguá' and '9783-13' presented lower root yield, whereas 'BRS Tapioqueira' and 'Irará had the highest root yield. Few leaves coupled with the highest water use efficiency for $\mathrm{CO}$, assimilation was found in 'BRS Kiriris' in contrast to 'BRS Jarina' and '9783-13'. 'BRS Caipira' had high proline content in both Umbaúba and Frei Paulo areas, traits usually associated to drought tolerance, that contribute to the adaptation. It is also important to consider that cultivar 'BRS Caipira' was the first to present increase in chlorophyll content after extended period of drought, that indicates a faster recovery after dry season. Furthermore, the results indicated that the most adapted cultivars for cultivation in this area are 'Irara', 'BRS Tapioqueira', 'BRS Kiriris' and 'BRS Caipira'.

Key words: Manihot esculenta, adaptation, osmotic adjustment photosynthesis, chlorophyll.

\section{RESUMO}

Dez cultivares de mandioca foram cultivadas no campo e avaliadas para identificar a mais adaptada aos Tabuleiros Costeiros do Nordeste do Brasil. As cultivares apresentaram diferenças nos teores de prolina e clorofila, altura, número de folhas e ramos, área de copa e produção de raízes, no entanto, não diferiram quanto às taxas fotossintéticas. As cultivares 'Tianguá'e '9783-13' apresentaram menor rendimento de raizes e 'BRS Tapioqueira'e 'Irará 'maior rendimento. Poucas folhas e maior eficiência no uso da água para a assimilação de $\mathrm{CO}_{2}$ foi verificado em 'BRS Kiriris', em contraste com 'BRS
Jarina' e '9783-13'. 'BRS Caipira' teve alto teor de prolina em Umbaúba e em Frei Paulo, características geralmente associadas à tolerância à seca, que contribuem para adaptação. Também é importante considerar que a cultivar 'BRS Caipira' foi a primeira a apresentar aumento no teor de clorofila após longo período de seca, o que indica recuperação mais rápida após período seco. Além disso, os resultados indicam que as cultivares mais adaptadas ao cultivo nessa área são 'Irará', 'BRS Tapioqueira', 'BRS Kiriris'e 'BRS Caipira'.

Palavras-chave: Manihot esculenta, adaptação, ajuste osmótico, fotossintese, clorofila.

\section{INTRODUCTION}

The cassava plant (Manihot esculenta Crantz, Euphorbiaceae) is a short lived perennial tropical shrub growing from about $1.0-3.5 \mathrm{~m}$ tall (OGUNTUNDE, 2005). It is one of the twenty mostproduced food and the sixth most consumed in the world, especially in tropical and sub-tropical regions of Africa, Asia and Latin America. This is because cassava is an important source of starch for many people around the world, being considered tolerant to drought and low soil fertility, and develops in different climatic conditions (EL-SHARKAWY, 2004; NJINE, 2010; FAO, 2015). In Brazil, cassava is the third most cultivated plant as a food crop, after sugarcane and soybeans, despite of the low productivity, particularly in northeast (IBGE, 2014).

\footnotetext{
IEmbrapa Tabuleiros Costeiros, Av. Beira Mar, 3250, 49025-040, Aracaju, SE, Brasil. E-mail: luciana.carvalho@embrapa.br. ${ }^{*}$ Corresponding author.

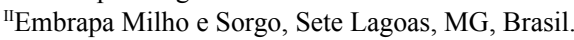

IIIEmbrapa Mandioca e Fruticultura, Cruz das Almas, BA, Brasil. 
Over the years, the cassava breeding has developed highly productive cultivars, and consequently, the root yield increased from 9 to $60 \mathrm{t} \cdot \mathrm{ha}^{-1}$ in many parts of the country (FUKUDA et al., 2002). However, the yield obtained by the small farmers is still far below the potential productivity even using more productive cultivars. Climatic events, such as dry spells and extended drought, degraded soil, pests and diseases usually are involved among the main causes of low yield (El-SHARKAWY, 2004). In most of the situations, these factors contributed to the decrease in the available leaf area for intercepting solar radiation and carbon assimilation (ALVES \& SETTER, 2004). Although the cassava plants have an inherent tolerance to extended drought stress, due to several physiological mechanisms that enable them to withstand more than three months without rain, their productivity is higher when moisture availability is not limiting (El-SHARKAWY, 2004). The objective of this study was identify the cassava cultivars from Brazilian Germplasm Bank with the greatest potential for drought tolerance and; therefore, more adapted to the environmental conditions of the Coastal Tableland of Northeast Brazil.

\section{MATERIALS AND METHODS}

In the current study, cassava cultivars obtained from the cassava trials network for the Brazilian Northeast, coordinated by EMBRAPA Coastal Tablelands were evaluated under field conditions: 'BRS Kiriris', 'Irará', 'Tianguá', 'BRS Verdinha', 'BRS Caipira', 'BRS' Poti Branca', 'BRS Jarina', 'BRS Tapioqueira', 'Preta do Sul' and hybrid '9783-13'. Stem cuttings with $20 \mathrm{~cm}$ were vertically planted in furrows $10 \mathrm{~cm}$ deep along August 2013. Cassava plants were grown in four rows of $6 \mathrm{~m}$ length at $1.0 \mathrm{~m} \times 0.6 \mathrm{~m}$, using a randomized completeblock-design with four replicates and ten treatments. Planting was done at the rainy season in order to ensure moisture availability for the initial growth without supplemental irrigation. Fertilization obeyed the results of soil analysis and recommendations for this crop (GOMES \& SILVA, 2006). The rainfall amount was recorded daily at field (Figure 1b). The trials were installed at the Experimental farm of

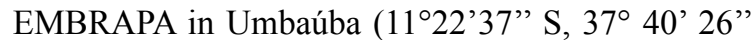
$\mathrm{W}, 109 \mathrm{~m})$, in the Coastal Tableland of Sergipe State, and in Frei Paulo(10³2'58'S, 37³2'04'W, 272m), in the Agreste of Sergipe State. The Coastal Tableland region is characterized by the presence of cohesive horizon in the soil, which limits water availability, rainy tropical climate with dry summer (type As, according to Koppen) and concentrated rain fall from

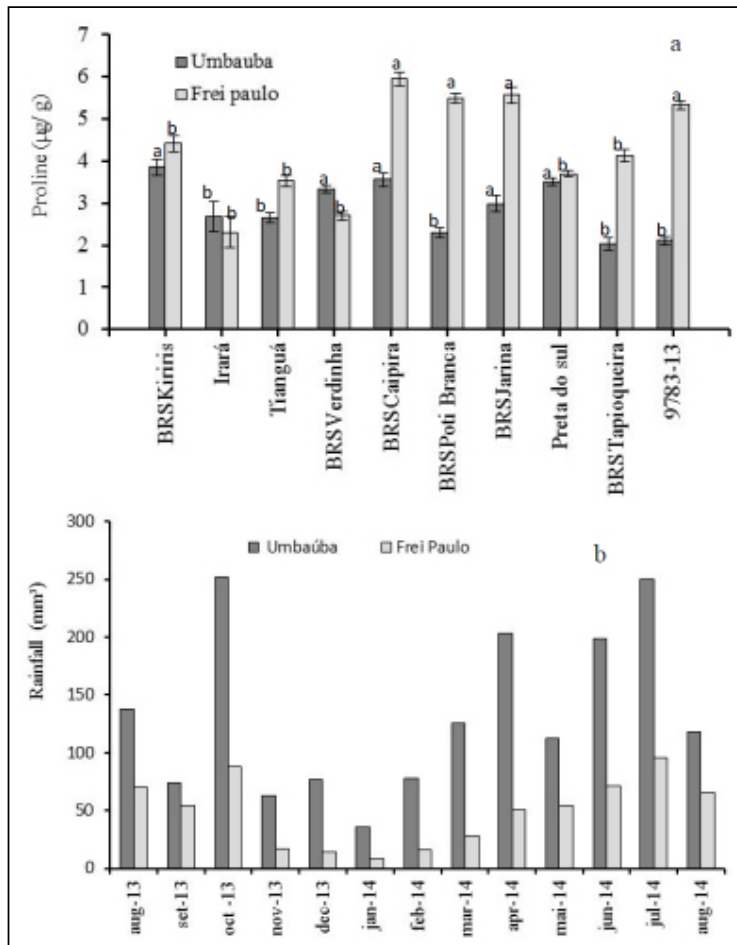

Figure 1 - (a) Proline content, in $\mu \mathrm{mol} \cdot \mathrm{g}^{-1}$ fresh weight, determined in January 2013 in cassava cultivars (Manhihot esculenta) grown in Umbaúba and Frei Paulo, Sergipe State. Proline data are expressed as means from five replicates, bars represent the standard deviation and columns followed by the same letter do not differ to $5 \%$ by Scott-Knott test. (b) Rainfall, in $\mathrm{mm}$, in the experimental areas in Umbaúba and Frei Paulo, Sergipe State, Brazil.

April to October, while the Agreste did not have cohesive horizon in the soil.

At three months after planting, plant height, and canopy area were calculated based on its two measurements perpendicular to the canopy, and the number of leaves and branches, rated by direct counting were evaluated. At the fifth month, on January, $0.5 \mathrm{~g}$ samples of the central leaflet from two expanded leaves of the top third were removed for determination of proline content, in accordance to the methodology of BATES et al. (1973). The relative chlorophyll content was estimated at the fifth (January, first evaluation date) and eighth month (April) of cultivation through a chlorometer (model CCM-200, Opti-Science, EUA), at intermedia position of the leaflet. Leaf photosynthetic $\left(\mathrm{P}_{\mathrm{N}}\right)$ and transpiration rates (E) were measured in April, on the same date, between 09:00-11:00h, using an infra-red gas analyzer (model LCPRO+, ADC., Hoddesdonm, UK). The average temperature was around $30^{\circ} \mathrm{C}$ during measurements (09:00-11:00), the ambient $\mathrm{CO}_{2}$ was about 355ppm and 
artificial irradiance was $1,100 \mu \mathrm{mol} \mathrm{m} \mathrm{m}^{-2} \mathrm{~s}^{-1}$. Based on these data and in accordance with LARCHER (2000), the actual water use ratio (A/ E) was estimated. Tubers were harvested after thirteen months, when plant height, root size, fresh shoot mass, root dry mass and root yield were measured.

All measurements described were done on trial carried out in Umbaúba-SE. In addition, another experiment was conducted, at the same time, in Frei Paulo-SE, where tubers could not be harvested due to the bird attack prior to harvest that caused the death of many plants. Data was evaluated for normal distribution by the Shapiro-Wills test, and for homogeneity of variance, through the Bartlet test with the $\mathrm{R}$ statistical software. Analysis of variance was performed for each character measured or calculated and mean values were compared using Scott-knott test by Sisvar statistical program.

\section{RESULTS AND DISCUSSION}

There were significant differences among the cultivars on the proline content, which have relatively small ranges (Figure 1a). They varied from 2.1 to $3.85 \mu \mathrm{mol} \mathrm{g}^{-1}$, in Umbaúba and from 2.3 to $6.84 \mu \mathrm{mol} \mathrm{g}^{-1}$, in Frei Paulo. The greatest contents were determined in 'BRS Kiriris', 'BRS Caipira', 'BRS Verdinha', 'BRS Jarina' and 'Preta do Sul', in Umbaúba, and in 'BRS Jarina', 'BRS Caipira', 'BRS Poti Branca' and hybrid '9783-13', at Frei Paulo. The averages, particularly in Frei Paulo, were higher than those reported by ALVES \& SETTER (2004), to cassava plants grown under controlled greenhouse conditions $\left(1.7 \mu \mathrm{mol} \mathrm{g}^{-1}\right)$ and similar to those reported by BABITA et al. (2010) to 'castor beans', Ricinus communis, at India $\left(3.9 \mu \mathrm{mol} \mathrm{g}^{-1}\right)$, and by SANTOS et al. (2013), to 'pinhão manso', Jatropha curcas, at the Coastal Tableland area of Rio Largo-AL $\left(5 \mu \mathrm{mol} \mathrm{g} \mathrm{g}^{-1}\right)$, under water deficit. Considering the proline accumulation as an indicator of drought tolerance on plants, in accordance to LIU et al. (2011), due to the osmotic adjustment, it is suggested that proline content may contribute to drought tolerance unless on those cultivars with the highest contents.

The highest relative chlorophyll content in leaves was reported in January, during dry season (Figure 1b), to cultivars 'Tianguá' and '978313' (Table 1). Considering that chlorophyll is the photosynthetic pigment related to solar radiation interception, this data indicated that these cultivars may be more productive than others. However, it was verified a decrease in chlorophyll content in most of cultivars from January to April, except to 'BRS Caipira' and 'BRS Jarina'. This reduction is usually recognized as a common negative consequence from water stress. Conversely, it has also been understood as an adaptive mechanism for plants suffering water shortage. During this time, a decrease in the solar radiation interception would contribute to reduce damage on photosynthetic apparatus caused by reactive oxygen molecules (MUNNÉ-BOSCH \& ALEGRE, 2000; LIU et al., 2011).

Increase in relative chlorophyll content, as verified in 'BRS Caipira', was described by MOURA

Table 1 - Averages of relative chlorophyll content in late January and early April for net photosynthetic $\mathrm{CO}_{2}$ assimilation rate $\left(\mathrm{A}, \mathrm{Mol}_{\mathrm{CO}}\right.$ $\left.\mathrm{m}^{-2} \mathrm{~s}^{-1}\right)$ to fully expanded individual leaves, transpiratory rate (E; in $\left.\mu \mathrm{mol} \mathrm{H}_{2} \mathrm{Om}^{2 \cdot} \mathrm{s}^{-1}\right)$ and the actual water use efficiency rate (A/E) of the cassava cultivars (Manihot esculenta), grown in Umbaúba-SE from August 2013 to August 2014.

\begin{tabular}{|c|c|c|c|c|c|}
\hline \multirow{2}{*}{ Cultivars } & -- & ---- & \multirow{2}{*}{ A } & \multirow{2}{*}{$\mathrm{E}$} & \multirow{2}{*}{$\mathrm{A} / \mathrm{E}$} \\
\hline & January & April & & & \\
\hline 'BRSKiriris' & $29.33 \mathrm{dA}$ & $24.30 \mathrm{~dB}$ & $21.86 \mathrm{a}$ & $4.70 \mathrm{a}$ & $4.65 \mathrm{a}$ \\
\hline 'Irará' & $32.73 \mathrm{cA}$ & $26.82 \mathrm{~dB}$ & $20.48 \mathrm{a}$ & $4.23 \mathrm{a}$ & $4.85 \mathrm{a}$ \\
\hline 'Tianguá' & $42.93 \mathrm{aA}$ & $34.62 \mathrm{bB}$ & $22.62 \mathrm{a}$ & $4.68 \mathrm{a}$ & $4.83 \mathrm{a}$ \\
\hline 'BRS Verdinha' & $29.92 \mathrm{dA}$ & $20.76 \mathrm{eB}$ & $22.11 \mathrm{a}$ & $4.68 \mathrm{a}$ & $4.76 \mathrm{a}$ \\
\hline 'BRSCaipira' & $32.57 \mathrm{cB}$ & $38.50 \mathrm{aA}$ & $19.67 \mathrm{a}$ & $4.31 \mathrm{a}$ & $4.57 \mathrm{a}$ \\
\hline 'BRS Poti Branca' & $29.32 \mathrm{dA}$ & $25.26 \mathrm{~dB}$ & $22.21 \mathrm{a}$ & $4.93 \mathrm{a}$ & $4.50 \mathrm{a}$ \\
\hline 'BRSJarina' & $27.91 \mathrm{dA}$ & $30.18 \mathrm{cA}$ & $20.57 \mathrm{a}$ & $4.33 \mathrm{a}$ & $4.75 \mathrm{a}$ \\
\hline 'BRSTapioqueira' & $31.54 \mathrm{cA}$ & $26.51 \mathrm{~dB}$ & $18.47 \mathrm{a}$ & $3.87 \mathrm{a}$ & $4.77 \mathrm{a}$ \\
\hline 'Preta do Sul' & $36.89 \mathrm{bA}$ & $30.84 \mathrm{cB}$ & $20.27 \mathrm{a}$ & $4.09 \mathrm{a}$ & $5.00 \mathrm{a}$ \\
\hline '9783-13' & $41.70 \mathrm{aA}$ & $33.88 \mathrm{bB}$ & $21.24 \mathrm{a}$ & $4.55 \mathrm{a}$ & $3.62 \mathrm{a}$ \\
\hline General mean & $33.48 \mathrm{~A}$ & $29.17 \mathrm{~B}$ & 20.95 & 4.72 & 4.63 \\
\hline $\mathrm{CV}(\%)$ & 6.25 & 7.15 & 6.99 & 13.88 & 12.90 \\
\hline
\end{tabular}

Means followed by the same lower case letter in columns, and capitalized on the lines, do not differ to $5 \%$ by the Scott-Knott test.

Ciência Rural, v.46, n.5, mai, 2016. 
(2010) to "pinhão manso" plants, as a result of changings in chlorophyll $\mathrm{a} / \mathrm{b}$ ratio between $30^{\circ}$ and $120^{\circ}$ days of water deficit, suggesting that there was an adaptive response to water deficit. Increase in chlorophyll a/ b ratio may provide greater intensity on color of the leaves, and it has been considered as adaptive characteristic for enabling reduction in the number of peripheral complexes responsible for intercepting solar radiation (LIU et al., 2011). Additionally, in accordance to the proposition of MUNNÉ-BOSCH \& ALEGRE (2000), it is suggested that the increase in relative content chlorophyll in 'BRS Caipira' after water stress may become the photosynthetic apparatus susceptible for the following water stresses.

Although there were no significant differences among the cassava cultivars for the photosynthetic $\mathrm{CO}_{2}$ assimilation and the water use efficiency for transpiration (Table 1) on Umbaúba conditions, it was verified greater averages on 'Tianguá', 'BRS Verdinha', 'BRS Kiriris' and 'BRS Poti Branca' cultivars. Conversely there was a significant difference among cultivars in relation to these rates at Frei Paulo experiment. Above mentioned cultivars, 'BRS Poti Branca', had the highest average assimilation rate (Table 2). According to EL-SHARKAWY (2007), the photosynthetic process is not inhibited on cassava plants, which are subjected to water deficit because of its inherent tolerance to drought. It is noteworthy also that 'BRS Kiriris' plants lost less water by evaporation and; therefore, had greater efficiency in water use, while

Table 2 - Net assimilation rate of $\mathrm{CO}_{2}\left(\mathrm{~A} ; \mu\right.$ molCO $\left.\mathrm{m}^{-2} \mathrm{~s}^{-1}\right)$ transpiratory $\left(\mathrm{E} ; \mu \mathrm{molH}_{2} \mathrm{O} \mathrm{m}^{-2} \mathrm{~s}^{-1}\right)$ and actual water use efficiency rate $(\mathrm{A} / \mathrm{E})$ means obtained in April from the cassava cultivars (Manihot esculenta) grown in Frei Paulo-SE. from August 2013 to August 2014.

\begin{tabular}{lcll}
\hline Cultivars & $\mathrm{A}$ & \multicolumn{1}{c}{$\mathrm{E}$} & $\mathrm{A} / \mathrm{E}$ \\
\hline 'BRS Kiriris' & $21.75 \mathrm{a}$ & $1.40 \mathrm{~d}$ & $16.11 \mathrm{a}$ \\
'Irará' & $18.41 \mathrm{a}$ & $1.74 \mathrm{c}$ & $11.98 \mathrm{~b}$ \\
'Tianguá' & $19.10 \mathrm{a}$ & $2.11 \mathrm{c}$ & $9.19 \mathrm{~b}$ \\
'BRS Verdinha' & $20.01 \mathrm{a}$ & $1.89 \mathrm{c}$ & $11.03 \mathrm{~b}$ \\
'BRSCaipira' & $10.21 \mathrm{c}$ & $1.83 \mathrm{c}$ & $5.58 \mathrm{c}$ \\
'BRS Poti Branca' & $15.30 \mathrm{~b}$ & $2.42 \mathrm{~b}$ & $6.34 \mathrm{c}$ \\
'BRSJarina' & $15.81 \mathrm{~b}$ & $3.20 \mathrm{a}$ & $4.98 \mathrm{c}$ \\
General average & 15.23 & 4.72 & 9.32 \\
CV (\%) & 11.72 & 12.81 & 11.20 \\
\hline
\end{tabular}

Means followed by the same lower case letter in columns do not differ to $5 \%$ by the Scott-Knott test. Data in columns refers to the average of three replicates.
'BRS Jarina' lost more water by evaporation. Besides, 'BRS Verdinha', 'Irará' and 'Tianguá' cultivars did not significantly differ for $\mathrm{CO}_{2}$ assimilation rate. It is suggested that at Frei Paulo conditions, where moisture availability was lower (Figure 1b), the differences among cultivars were more prominent.

According to EL-SHARKAWY (2004), usually the above-ground organs are the main drain for assimilates in early development, while the roots become the main sink in the end. However, it was found that the cultivars 'BRS Verdinha' and 'BRS Poti Branca' were two of the shortest on the first months after planting, and two of the highest in the harvest period (Table 2).

Based on results, it is suggested that the greatest increase in the plant height, verified in these cultivars, probably was favored by a greater amount of photoassimilates driven to the shoot, at the expense of roots which could explain the low root productivity (Table 3), and can be related to shadowing. The highest canopy area and consequently the greatest surface for water loss and $\mathrm{CO}_{2}$ uptake were observed in plants of 'BRS Tapioqueira' and 'BRS Caipira', which did not significantly differ from 'BRS Jarina', 'BRS Verdinha', 'Irará', 'Tianguá' and hybrid '978313' (Table 2). Based on these data, it is suggested that those cultivars with higher plant height have larger vegetative vigor in the early months of development than others. There was also high amount of dry matter in 'BRS Caipira', '9783-13' and 'BRS Tapioqueira', and greater productivity for the last and 'Irará' (Table 4), confirming El-Sharkawy proposition (2007) about the increased productivity of plants with higher vegetative vigor. The largest surface contributes to the higher susceptibility to drought.

Fewer leaves was recorded in plants of cultivars 'Preta do Sul', 'Irará', 'BRS Tapioqueira', 'BRS Caipira', 'BRS Verdinha' and '9783-13', and lower canopy in 'BRS Poti Branca', 'Preta do Sul' and 'BRS Kiriris'. Based on plant height and number of leaves, it is suggested that 'Preta do Sul' and 'BRS Verdinha' had less vigor at the firstmonths. According to ALVES \& SETTER (2004), the reduction in leaf area, verified in cassava plants under water stress, occurs as a way of limiting the increase in surface and hence keeping the source-sink relationship. Except for cultivar 'Preta do Sul', which had the lower canopy, 'BRS Kiriris' and'BRS Poti Branca', could not be explained by fewer leaves, but by fewer branches (Table 2), and its lower length. Moreover, 'BRS Kiriris' and 'BRS Poti Branca' were two of cultivars with the highest number of leaves distributed in a small canopy. Additionally, EL-SHARKAWY\& 
Table 3 - Leaves number.branches.canopy area and total height means of cassava (Manihot esculenta) cultivars in November 2013 and August 2014 in Umbaúba-SE. Brazil.

\begin{tabular}{|c|c|c|c|c|c|c|}
\hline \multirow{3}{*}{ Cultivars } & \multicolumn{4}{|c|}{--------------------------------------November/13-------------------------------------- } & \multirow[t]{2}{*}{ August/14 } & \multirow[t]{2}{*}{ Nov.-Aug. } \\
\hline & Leaves & Branchs & Canopy & ----------. & & \\
\hline & $\left(\mathrm{n}^{\mathrm{o}}\right)$ & $\left(\mathrm{n}^{\mathrm{o}}\right)$ & $\left(\mathrm{m}^{2}\right)$ & $(\mathrm{m})$ & $(\mathrm{m})$ & (\% increase) \\
\hline 'BRS Kiriris' & $46.4 \mathrm{a}$ & $1.6 \mathrm{~b}$ & $0.550 \mathrm{~b}$ & $0.712 \mathrm{a}$ & $2.17 \mathrm{a}$ & 304.8 \\
\hline 'Irará' & $31.6 \mathrm{~b}$ & $1.0 \mathrm{c}$ & $0.669 \mathrm{a}$ & $0.786 \mathrm{a}$ & $2.59 \mathrm{a}$ & 329.5 \\
\hline 'Tianguá' & $65.6 \mathrm{a}$ & $2.0 \mathrm{~b}$ & $0.651 \mathrm{a}$ & $0.788 \mathrm{a}$ & $1.63 \mathrm{~b}$ & 206.9 \\
\hline 'BRS Verdinha' & $39.2 \mathrm{~b}$ & $1.0 \mathrm{c}$ & $0.610 \mathrm{a}$ & $0.616 \mathrm{~b}$ & $2.21 \mathrm{a}$ & 358.8 \\
\hline 'BRS Caipira' & $37.2 \mathrm{~b}$ & $1.0 \mathrm{c}$ & $0.713 \mathrm{a}$ & $0.716 \mathrm{a}$ & $2.27 \mathrm{a}$ & 317.0 \\
\hline 'BRS Poti Branca' & $46.8 \mathrm{a}$ & $1.8 \mathrm{~b}$ & $0.510 \mathrm{~b}$ & $0.668 \mathrm{~b}$ & $2.62 \mathrm{a}$ & 392.2 \\
\hline 'BRS Jarina' & $49.6 \mathrm{a}$ & $2.8 \mathrm{a}$ & $0.694 \mathrm{a}$ & $0.812 \mathrm{a}$ & $1.86 \mathrm{~b}$ & 229.0 \\
\hline 'BRS Tapioqueira' & $33.6 \mathrm{~b}$ & $1.0 \mathrm{c}$ & $0.726 \mathrm{a}$ & $0.886 \mathrm{a}$ & $2.26 \mathrm{a}$ & 255.0 \\
\hline 'Preta do Sul' & $31.8 \mathrm{~b}$ & $1.0 \mathrm{c}$ & $0.441 \mathrm{~b}$ & $0.552 \mathrm{~b}$ & $2.01 \mathrm{~b}$ & 364.1 \\
\hline '9783-13' & $31.4 \mathrm{~b}$ & $1.0 \mathrm{c}$ & $0.711 \mathrm{a}$ & $0.748 \mathrm{a}$ & $2.38 \mathrm{a}$ & 318.2 \\
\hline General average & 41.32 & 1.42 & 0.627 & 0.730 & 2.18 & 298.6 \\
\hline $\mathrm{CV}(\%)$ & 14.05 & 15.9 & 20.67 & 11.21 & 10.25 & \\
\hline
\end{tabular}

Means followed by the same letter in columns do not differ to $5 \%$ by the Scott-Knott test.

Data in columns refers to the average of five replicates.

TAFUR (2010) proposed that the storage root formation and subsequent filling processes require a greater amount of assimilates in shorter cultivars than in the highest cultivars. Based on this information, it is suggested that the cultivars with lower height, such as 'Preta do Sul', would be more likely to present lower productivity in water stress conditions than cultivars with higher height, as 'BRS Tapioqueira'.
Considering the distance between two plants in the same row $(0.6 \mathrm{~m})$ and the average area of the canopy $\left(0.63 \mathrm{~m}^{2}\right.$; Table 2$)$, it is suggested that there was shading in the rows for all cultivars, except for the plants of cultivars 'Preta do Sul', 'BRS Kiriris' and 'BRS Poti Branca'. Based on these data, it is recommended to increase the planting spacing for most cultivars, especially

Table 4 - Leaves number.branches.canopy area and total height means of cassava (Manihot esculenta) cultivars in November 2013 and August 2014 in Umbaúba-SE. Brazil.

\begin{tabular}{|c|c|c|c|c|c|c|}
\hline \multirow{3}{*}{ Cultivars } & \multirow{3}{*}{$\begin{array}{c}\text { Leaves } \\
\left(\mathrm{n}^{\circ}\right)\end{array}$} & \multirow{3}{*}{$\begin{array}{c}\text { Branchs } \\
\left(\mathrm{n}^{\circ}\right)\end{array}$} & \multirow{3}{*}{$\begin{array}{c}\text { Canopy } \\
\left(\mathrm{m}^{2}\right)\end{array}$} & -------- & \multirow[t]{2}{*}{ August/14 } & \multirow[t]{2}{*}{ Nov.-Aug. } \\
\hline & & & & --------. & & \\
\hline & & & & $(\mathrm{m})$ & $(\mathrm{m})$ & (\% increase) \\
\hline 'BRS Kiriris' & $46.4 \mathrm{a}$ & $1.6 \mathrm{~b}$ & $0.550 \mathrm{~b}$ & $0.712 \mathrm{a}$ & $2.17 \mathrm{a}$ & 304.8 \\
\hline 'Irará' & $31.6 \mathrm{~b}$ & $1.0 \mathrm{c}$ & $0.669 \mathrm{a}$ & $0.786 \mathrm{a}$ & $2.59 \mathrm{a}$ & 329.5 \\
\hline 'Tianguá' & $65.6 \mathrm{a}$ & $2.0 \mathrm{~b}$ & $0.651 \mathrm{a}$ & $0.788 \mathrm{a}$ & $1.63 \mathrm{~b}$ & 206.9 \\
\hline 'BRS Verdinha' & $39.2 \mathrm{~b}$ & $1.0 \mathrm{c}$ & $0.610 \mathrm{a}$ & $0.616 \mathrm{~b}$ & $2.21 \mathrm{a}$ & 358.8 \\
\hline 'BRS Caipira' & $37.2 \mathrm{~b}$ & $1.0 \mathrm{c}$ & $0.713 \mathrm{a}$ & $0.716 \mathrm{a}$ & $2.27 \mathrm{a}$ & 317.0 \\
\hline 'BRS Poti Branca' & $46.8 \mathrm{a}$ & $1.8 \mathrm{~b}$ & $0.510 \mathrm{~b}$ & $0.668 \mathrm{~b}$ & $2.62 \mathrm{a}$ & 392.2 \\
\hline 'BRS Jarina' & $49.6 \mathrm{a}$ & $2.8 \mathrm{a}$ & $0.694 \mathrm{a}$ & $0.812 \mathrm{a}$ & $1.86 \mathrm{~b}$ & 229.0 \\
\hline 'BRS Tapioqueira' & $33.6 \mathrm{~b}$ & $1.0 \mathrm{c}$ & $0.726 \mathrm{a}$ & $0.886 \mathrm{a}$ & $2.26 \mathrm{a}$ & 255.0 \\
\hline 'Preta do Sul' & $31.8 \mathrm{~b}$ & $1.0 \mathrm{c}$ & $0.441 \mathrm{~b}$ & $0.552 \mathrm{~b}$ & $2.01 \mathrm{~b}$ & 364.1 \\
\hline '9783-13' & $31.4 \mathrm{~b}$ & $1.0 \mathrm{c}$ & $0.711 \mathrm{a}$ & $0.748 \mathrm{a}$ & $2.38 \mathrm{a}$ & 318.2 \\
\hline General average & 41.32 & 1.42 & 0.627 & 0.730 & 2.18 & 298.6 \\
\hline $\mathrm{CV}(\%)$ & 14.05 & 15.9 & 20.67 & 11.21 & 10.25 & \\
\hline
\end{tabular}

Means followed by the same letter in columns do not differ to $5 \%$ by the Scott-Knott test.

Data in columns refers to the average of five replicates. 
for 'BRS Tapioqueira, 'BRS Caipira', '9783-13' and 'BRS Jarina', in order to favor greater light interception by plants. The stimulation on growth of the main stem, according to SILVA et al. (2013), allows plants to rise above the surrounding plants in an attempt to overcome the shading. Cultivars 'BRS Caipira', 'Irará', 'BRS Verdinha', 'BRS Tapioqueira', 'Preta do Sul' and '9783-13'were those with fewer branches. In agreement with the proposal by LARCHER (2000) about the reduction in turgescence and the consequent decrease in the growth process in response to drought, there was a reduction in the growth in plant height of the cultivars 'BRS Jarina' and 'Tianguá' (Table 2). In addition, there was low root productivity, especially in cultivar 'Tianguá' (Table 3), suggesting less tolerance to extended drought.

It was concluded that the most appropriate cultivars to growing in the Coastal Tablelands of Sergipe are 'Irará', 'BRS Tapioqueira', which have greater productivity in these conditions, 'BRS Kiriris', which had more drought tolerance attributes, and 'BRS Caipira', in the absence of dry spells, due to be highly productive and able to recover more quickly after stressful conditions. In addition, it is concluded that although 'Tianguá' and ' $9783-13$ ' have the greatest productive potential, they are less tolerant to extended drought stress than others.

\section{ACKNOWLEDGEMENTS}

We thank the Fundação de Amparo à Pesquisa e à Inovação Tecnológica do Estado de Sergipe (FAPITEC/SE) (N. 019.203.01232/2011-1) for funding the project under which this work has been accomplished.

\section{REFERENCES}

ALVES, A.A.C; SETTER, T.L. Abscisic acid accumulation and osmotic adjustment in cassava under water deficit. Environmental and Experimental Botany, v.51, p.259-271, 2004. Available from: $<\mathrm{https} / /$ dl.sciencesocieties.org/publications/cs/pdfs/40/1/131>. Acessed: Feb. 2, 2015. doi: 10.1016/j.envexbot.2003.11.005.

BABITA, M. et al. Osmotic adjustment, drought tolerance and yield in castor (Ricinus communis L.) hybrids. Environmental and Experimental Botany, v.69, p.243-249, 2010. Available from: $<$ http://www.sciencedirect. com/science/article/pii/S0098847210001176>. Acessed: Mar. 15, 2015. doi: 10.1016/j.envexpbot.2010.05.006

BATES, L.S. et al. Rapid determination of free proline for waterstress studies. Plant Soil, v.39, p.205-207, 1973. Available from: $<$ http://link.springer.com/article/10.1007/BF00018060\#page-1>. Acessed: Jan. 20, 2010.

EL-SHARKAWY, M.A. Cassava biology and physiology. Plant Molecular Biology, v.56, p.481-501, 2004.
EL-SHARKAWY, M.A. Physiological characteristics of cassava tolerance to prolonged drought in the tropics: implications for breeding cultivars adapted to seasonally dry and semiarid environments. Brazilian Journal of Plant Physiology, v.19, p.257-286, 2007. Available from: $<$ http://www. scielo.br/pdf/bjpp/v19n4/a03v19n4.pdf >. Acessed: Feb. 15, 2015.

EL-SHARKAWY, M.A.; TAFUR, S.M. Comparative photosynthesis, growth, productivity, and nutrient use efficiency among tall- and short-stemmed rain-fed cassava cultivars. Photosynthetica, v.48, p.173-188, 2010.

FAO. Food and agriculture organization of the United Nations Statistics division. Available from: <http:/faostat3.fao.org/browse/rankings/ commodities_by_regions $>$. Accessed: Jul.2015.

FUKUDA,W.M.G. et al. Clones de mandioca resistentes à podridão de raízes recomendados para o estado de Sergipe. Cruz das Almas: Embrapa Mandioca e Fruticultura, 2000. (Circular Técnica, 46).

GOMES, J.C.; SILVA, J. Correção da acidez e adubação. In: SOUZA L.S.et al. (Eds.). Aspectos socioeconômicos e agronômicos da mandioca. Cruz das Almas: Embrapa Mandioca e Fruticultura, 2006. p.215-247.

IBGE. Produção Agrícola municipal. Culturas temporárias e permanentes, 2010, v.37, p.1-91. Available from: <http://www. ibge.gov.br/home/estatística/economia/PAM/2010/ publicação_ completa.pdf $>$. Accessed: Jul. 2014.

LARCHER, W. Ecofisiologia vegetal. São Carlos-SP: Rima Artes e textos, 2000. 531p

LIU, C. et al. Effect of drought on pigments, osmotic adjustment and antioxidant enzymes in six woody plant species in karst habitats of southwestern China. Environmental and Experimental Botany, v.71, p.174-183, 2011. Available from: <http://www.sciencedirect.com/ science/article/pii/S009884721000256X>. Acessed: Mar. 15, 2015.

MOURA, A.R. Aspectos morfológicos, fisiológicos e bioquímicos do pinhão manso (Jatropha curcas L.) submetido ao déficit hídrico. 2010. 81f. Dissertação (Mestrado em Ciências Florestais) - Universidade Federal Rural de Pernambuco - UFRPE, Departamento de Ciência Florestal, PE.

MUNNÉ-BOSCH, S.; ALEGRE, L. Changes in carotenoids, tocopherols and diterpenes during drought and recovery, and the biological significance of chlorophyll loss in Rosmarinus oficinalis plants. Planta, v.210, p.925931, 2000. Available from: <http://link.springer.com/article/10.1007/ s004250050699\#page-1>. Acessed: Apr. 10, 2015.

NJINE, N.W. Social and economic factors hindering adoption of improved cassava varieties in Kigajo, Kenya. Journal of Developments in Sustainable Agriculture, v.5, p.178-190, 2010.

OGUNTUNDE, P.G. Whole-plant water use and canopy conductance of cassava under limited available soil water and varying evaporative demand. Plant and Soil, v.278, p.371-383, 2005. Available from: $<$ http://link.springer.com/article/10.1007/s11104-005-0375-z\#/ page-1>. Acessed: Feb. 8, 2015. doi: 10.1007/s11104-005-0375-z.

SANTOS, C.M. et al. Seasonal variations of photosynthesis, gas exchange, quantum efficiency of photosystem II and biochemical responses of Jatropha curcas L. grown in semi-humid and semi-arid areas subject to water stress. Industrial Crops and Products, v.41, p.203-213, 2013. Available from: <http://www.sciencedirect.com/ science/article/pii/S0926669012001938>. Acessed: Apr. 10, 2015.

SILVA, T.S. et al. Planting density and yield of cassava roots. Revista Ciência Agronômica, v.44, p.317-324, 2013. 